\title{
Specifics of the concepts of linguistic norm and variability
}

\author{
Y. Y. Terniievska \\ Luhansk Taras Shevchenko National University \\ Corresponding author. E-mail: yevgenia.ter@gmail.com \\ Paper received 28.08.20; Accepted for publication 15.09.20.
}

\begin{abstract}
https://doi.org/10.31174/SEND-Ph2020-234VIII69-16
\end{abstract}
Abstract. The article is devoted to the description of the concepts of the linguistic norm and variability, as well as the differentiation of the terms "variability", "variation" and "variance". In particular, the approaches of scientists to understanding these phenomena are analyzed, the most used definitions of them are given and the main differences between them are revealed.

Keywords: linguistic norm, variability, variation, variance, language variant.

Introduction. The language system is characterized by a certain set of properties that determine its functioning. Variability is one of them. The language system is arranged in such a way that each of its units functions in the form of one of its variants, the specifics of which are determined by the level to which this unit belongs. The issue of language variability does not lose its relevance today, as the language is constantly evolving and changing.

A brief overview of relevant publications. In domestic and foreign science R. Bell, V. Bondaletov, A. Fill, J. Fishman, M. Halliday, E. Haugen, K. Henson, E. Isayev, B. Johnstone, S. Kisling, L. Krysin, U. Labov, V. Pasynok, O. Petrenko, L. Prokopova, O. Selivanova, I. Shevchenko, V. Zhyrmunskyi and others dealt with the issues of the relationship between language norm and variability. In the works of such scientists as R. Avanesov, O. Bubennikova, J. Chambers, M. Makovskyi, D. Shakhbahova, O. Shveitser, M. Wakelin and others the considerable attention is given to the search for factors of language variation, but this issue still can not be considered as exhausted.

The objectives of the article are to characterize the concepts of language norm and variability, as well as to differentiate various terms related to these phenomena.

Description of the main material. The existence of language without a certain norm is impossible, because in order to perform its main communicative function, it must become generally accepted in a separate language group. Traditionally, the norm in linguistics is considered to be the set of the most stable, traditional realizations of the elements of the language structure, selected and fixed by the language practice [17, p. 555].

According to S. Yermolenko, the language norm is a set of language means that correspond to the language system and are perceived by its speakers as a model of social communication in a certain period of development of language and society [8, p. 420].

In linguistics the concept of language norm is considered in two dimensions:

1) norm as a result of historically and socially conditioned use of certain stereotypical models of language means usage [12];

2) norm as a result of purposeful regulation of language life by society and social institutions [11, p. 13].

The concept of norm is inherent to almost any concept of language. This is primarily due to the correctness of the individual's choice of a particular language form. The norm is the choice of a certain language demonstrators in accordance with the criteria of communicative activity and its use in accordance with the requirements of a specific type of communicative events [15].

Along with the concept of language norm, there is also the concept of language variability. Norms of literary language are closely related to variability at the lexical, grammatical, phonological levels [9].

Linking variance with the concept of norm, linguists pay attention to the fact that each modern literary language is characterized not only by a certain degree of stability of normative realizations, but also by a certain set of variant means. The category of variance is very important for the characterization of a literary norm, and the range of variance largely characterizes the specifics of the norms of different literary languages and is the basis for differentiation of some historical periods of their development [13, p. 82].

Each unit of language that belongs to any level of the language system can vary depending on the specific environment. This ability of the language unit became the basis for understanding the concept of variability and variance. It follows that the variability of language units is their ability to be modified depending on the context $[4, \mathrm{p}$. 45]. Having studied the patterns of functioning and development of language more deeply, we can understand that the variation of the language system is its normal natural state, because "every language changes in time and space" [23, p. 38].

In modern linguistics, the consideration of language variation is complicated by terminological ambiguity, because often the terms "variability" and "variance" are used synonymously. Variability is defined by scientists in different ways: as "partial changeability", "ability to change", "process of change" and so on. Linguists" understanding of the phenomenon of variability differs not only in its initial theoretical preconditions, but also in the breadth of interpretation of the phenomenon itself [19, $\mathrm{p}$. $31 ; 23$, p. 35].

In general, variability in linguistics is interpreted as a general social property and way of existence of the language system and language norm. It is a consequence of the language evolution and is related to its historical character, so the norm of literary language changes. In this case, the problem of norm and variability arises precisely in the period of coexistence of language variants, i.e. several different realizations of one language unit $[16, p$. 123].

Researcher B. Abramov emphasizes that variability is an essential property of all levels of the language system. He draws attention to the fact that "on the one hand, it feeds 
the evolutionary processes in language, and on the other hand, plays a major role in its functioning" [1, p. 5].

The scientist L. Barannikova notes that "variability appears both in the process of reflecting reality and expressing generalized mental images in the form perceived by the senses, i.e. in sound, and in the process of language functioning as the most important means of human communication. Variability is precisely the general property inherent to the very structure of the language system as a way of existence and functioning of all units of language, which reveals specific features within each level" [3, p. 19].

A separate direction of studying the language units variability is outlined in the research of D. Shakhbahova. Her analysis of the intonation peculiarities of English language variants makes a certain contribution to the development of a general theory of variability. The characteristics of the phonetic system of English language variants (English, American, Australian and Canadian) are given against the background of contrast analysis of "constant and variable" values. From the author's point of view, the language system has two mutually exclusive characteristics that form a single whole: constancy and variability. The constancy of the language system contributes to the preservation of basic system and structural elements, while the language system, constantly changing, tends to variability, continuing to be used by society as a means of communication [21].

Variability is manifested at all levels of linguistic communication: from the use of language units depending on the conditions of communication to the speaker's awareness of the admissibility of different options belonging to one language. Variability is especially obvious at the lexical level, which is the most open to new borrowings, although it is often manifested at other language levels [24, p. 12].

According to K. Horbachevych, the concept of variability should be applied to the word only if the material and semantic features of the language unit are taken into account at the same time and the word variant is defined as its regularly reproduced variations, which preserve the identity of morphological, word-forming structure, lexical and grammatical meaning and which differ either phonetically or by formative affixes. In contrast, variance should be considered as a consequence of language evolution [7, p. 3-17].

According to O. Akhmanova, variance should be understood as diversity, variety of speech, which are determined by the conditions of its use, as well as differences in social and territorial affiliation of speakers [2, p. 72].

Considering variance in the narrow sense, we talk about orthographic, phonetic, morphological, word-forming, syntactic variants. Bearing in mind the variability in a broader sense, one can consider the national-state language variants, territorial dialects within a language, various sociolects (by social affiliation, profession or interests), as well as linguistic peculiarities associated with differences in age and gender [20, p. 93].

In other words, the linguistic variance of language should be traced at its two levels: purely linguistic and sociocultural, so the study of variance at different levels of the language system should not be limited to the analysis of individual facts or their specific groups, it should be held within the framework of the general theory, when all the specificity of language units is manifested precisely in the interaction [6, p. 72].

In the history of literary language, namely in its written form, variance is manifested at the level of lexical, morphological and syntactic units. Accordingly, we can distinguish three groups of variants [13]:

1) Lexical variants are modifications, parallel forms of existence of the same word, which preserve the identity of lexical and grammatical meanings, stylistic homogeneity and undifferentiated compatibility under any modifications. Within the limits of lexical variance, such modifications are possible: 1) phonemic composition (phonemic variants), 2) affixes (word-forming variants). It is these indicators that can influence the change of lexical meaning.

2) Morphological variants include formal wordchanging modifications that do not change lexical and grammatical meanings and stylistic homogeneity under any circumstances. These are affixal variants of word forms with the grammatical meaning of the case, gender, number, time and mood. At the level of morphology, formal variation is possible in cases where two different forms can be interchangeable in the same position, while maintaining the same value. In contrast to phonemic variations within the lexical variation, which has a nonsystemic character and is present only in some tokens, morphological variation is a regular phenomenon.

3) Syntactic variants are modifications of word order and ways of combination in phrases, sentences with identical meaning. All possible syntactic changes in terms of synchrony are clearly regulated by the language norm, which provides language mechanisms that ensure the integrity of the entire language system.

Thus, we can consider variability as dynamics, the process of development and change of language, and variance - as a result of variability (dynamic changes in language), which is reflected in the language system and is manifested in the existence of certain language variants. Variability always indicates the presence of the ability to change. Variance is already fixed in the language, but variability has a potential driving force that lives constantly and causes certain language changes $[10$, p. 80].

Another term, variation, denotes the difference in the reproduction of language units, which consists in the change of their sound composition or structural meaning without losing their identity [2, p. 71]. O. Kubriakova characterizes variation from another point of view. She considers it a process and / or the result of the emergence in the initial unit of certain variants that modify it in one or another relation, or variants that do not change the essential characteristics and therefore do not violate the identity of the unit itself [14, p. 25].

The phenomenon of variability takes place not only in the internal structure of the language system, because almost every language exists in the form of a certain number of varieties, such as dialects, subdialects, territorial variants. These variant subsystems have their own special linguistic features, social and communicative functions $[5$, p. 6].

The use of certain variants may also depend on the conditions of speech: the style, genre, the degree of 
attention of the speaker to his or her own speech, the formality / informality of the situation, and so on. The same speakers can choose different options depending on the specified conditions [18].

Forming together a single macrosystem, language variants are inseparable and interdependent in their functioning. Therefore, the study of the functioning and development of language as a whole or its individual phenomena can not be limited to the study of only the standard variant of language. The more interdependent language variants are taken into account, the more likely it is to obtain reliable data. It should also be considered that the role of each of these language variants may change in different periods of history, so sometimes the appearance or disappearance of regional variants are not only possible, sometimes it is inevitable [22, p. 223]. However, this does not mean that the role of a language variant that has disappeared or emerged can be neglected, since very often the significance of such components of the language situation is quite large and must be taken into account.

It follows that language as a functional system is dynamic and remains in a state of constant motion. The consequence of linguistic evolution is the variability of language units inherent to language, which at the same time appears as a natural manifestation of changes taking place in language. The reasons for the appearance of variant forms are determined by both internal and external factors of language development. From the sociolinguistic point of view, the variability of language signs depends on both the social characteristics of native speakers (social differentiation) and the situation of speech communication (functional differentiation) [18, p. 120].

Conclusions. Thus, we can conclude that the consideration of the problems of language variability and the correlation of different variantological terms is complicated by the lack of a common standard terminology. Most often there is either a synonymous use of different concepts, or the use of certain terms without their specification. We hold the opinion that variability should be called such a property of language in general and language norms in particular, which makes it possible to change the content saturation of different-level language units under the influence of internal or external factors during natural evolution. In this case, variance should be understood as the ontological property of language as a system to accumulate alternative or variant sets of language units, which can be characterized by the signs of level, degree and limits of their changes. Due to the fact that the language is considered as a set of its variants, taking into account the territorial, social and other types of stratification, variability, variance and variation are extremely important linguistic phenomena that require further study.

\section{ЛІТЕРАТУРА}

1. Абрамов Б. А. Вариантность финитных конструкций (лексико-структурных основ предложений). Вариантность как свойство языковой системы. Ч.1. Москва: Наука, 1982. C. $35-36$.

2. Ахманова О.С. Словарь лингвистических терминов. Москва: Советская энциклопедия, 1966. 606 с.

3. Баранникова Л. И. О вариантных единицах диалектных систем. Проблемы истории и диалектологии славянских языков: сб. ст. к 70-летию чл.-кор. АН СССР В.И. Борковского. Москва: Наука, 1971. С. 31-38.

4. Вагана Ж., Бондаренко Е. В, Чернова О. О. Теоретические основания изучения проблемы языковой вариативности. Научные ведомости. Серия «Гуманитарные науки». № 6 (125). Выпуск 13. Белгород, 2012. С. 41-49.

5. Варианты полинациональных литературных языков / Жлуктенко Ю.А., Карабан В.И., Быховец Н.Н. и др.; под ред. Ю.А. Жлуктенко. Киев: Наукова думка, 1981. 280 с.

6. Гак В. Г. Языковая вариантность в свете общей теории вариантности (к проблеме факторов и роли вариантности в языке). Вариантность как свойство языковой системы. Тезисы докладов: в 2 ч. / отв. ред. Солнцев В. М. Москва: Наука, 1982. Ч. 1. С. 72-75.

7. Горбачевич К. С. Вариантность слова и языковая норма. Ленинград: Наука, 1978. 240 с.

8. Срмоленко С. Я. Норма мовна. Українська мова. Енциклопедія / редкол.: Русанівський В.М., Тараненко О.О. (співголова), М.П. Зяблюк та ін. Київ: Українська енциклопедія, 2004. С. 420-421.

9. Єрмоленко С. Я. Сучасна літературна мова і діалекти. URL: http://kulturamovy.univ.kiev.ua/KM/pdfs/Magazine62.pdf (дата звернення: 27.03.2018).

10. Жмаєва Н. С. Мовна норма й варіативність. Науковий вісник Південноукраїнського державного педагогічного університету ім. К.Д. Ушинського. Лінгвістичні науки. 2012. № 15. С. 74-82.

11. Ицкович В. А. Языковая норма. Москва: Просвещение, $1968.96 \mathrm{c}$.

12. Косериу Э. Синхрония, диахрония и история. Новое в лингвистике. Москва: Прогресс, 1963. Вып. 3. С. 143-343.

13. Коць Т. Явище варіантності в історії літературної мови. Українська мова. 2016. № 2. С. 82-91.

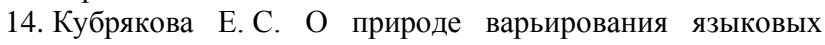
единиц и его основных типах. Всесоюзная конференция «Проблемы вариативности в германских языках». Тезисы докладов. Москва: Наука, 1988. С. 25-27.

15. Матезиус В. О лингвистической характерологии (на материале современного английского языка). Новое в зарубежной лингвистике. Контрастивная лингвистика / под ред. В.Г. Гака. Москва: Прогресс, 1989. Вып. XXV. С. $18-26$.

16. Мошнина Т. В. Динамика современной произносительной нормы английского языка. Звучащая речь: теория и практика: Сб. науч. трудов. Москва: МГЛУ, 2000. Вып. 453. С. 131-145.

17. Общее языкознание: Формы существования, функции, история языка / под ред. Б.А. Серебрянникова. Москва: Наука, 1990. 608 с.

18. Парфіненко А. Мовна варіативність у фокусі сучасних лінгвістичних досліджень (на матеріалі праць британських та американських вчених). Studia linguistica. 2013. Вип. 7. С. 116-120. URL: http://nbuv.gov.ua/jpdf/Stling_2013_7_21.pdf (дата звернення: 26.05.2019).

19. Солнцев В.М. Вариативность как общее свойство языковой системы. Вопросы языкознания. 1984. № 2. С. $31-42$.

20. Федотова Ю. Б. Актуальные проблемы языковой вариативности. Культура народов Причерноморья. 2011. № 203. С. 91-94.

21. Шахбагова Д. А. Фонетическая система английского языка в диахронии и синхронии (на материале британского, американского, австралийского, канадского вариантов английского языка). Москва: Высшая школа, $1982.128 \mathrm{c}$.

22. Ярцева В. Н. Развитие национального литературного английского языка. Москва: Наука, 1969. 286 с.

23. Ястрежембский В. Р. Языковая вариативность и 
лингвистическое объяснение. Проблемы языковой вариативности: сб. обзоров / отв. ред. Кузнецов А. М. Москва: ИНИОН, 1990. С. 35-57.
24. Barber Ch. Linguistic Change in Present-Day English Alabama Linguistic and Phonological Series (University of Alabama). Edinburgh; L.: Oliver and Boyd Ltd., 1964.

\section{REFERENCES}

1. Abramov, B.A. (1982). Variantnost finitnyh konstruktsiy (leksiko-strukturnyh osnov predlozheniy) [Variance of finite structures (lexico-structural foundations of sentences)]. In Variantnost kak svoystvo yazykovoy sistemy [Variation as a property of the language system]. Moscow: Nauka (pp. 35-36) [in Russian].

2. Ahmanova, O.S. (1966). Slovar lingvisticheskih terminov [Dictionary of linguistic terms]. Moscow: Sovetskaya entsiklopediya [in Russian].

3. Barannikova, L.I. (1971). O variantnyh edinitsah dialektnyh sistem [About variant units of dialect systems]. In Problemy istorii i dialektologii slavyanskih yazykov: sb. st. k 70-letiyu chl.-kor. AN SSSR V.I. Borkovskogo [Problems of history and dialectology of Slavic languages: collection of articles to the 70th anniversary of Corresponding Member of USSR Academy of Sciences V.I. Borkovsky]. Moscow: Nauka (pp. 31-38) [in Russian].

4. Vagana, Zh., Bondarenko, E.V, Chernova, O.O. (2012). Teoreticheskie osnovaniya izucheniya problemy yazykovoy variativnosti [Theoretical foundations of studyng the problem of linguistic variability]. Nauchnye vedomosti. Seriya "Gumanitarnye nauki" [Scientific statements. Series "Humanities"], 6 (125), Issue 13, 41-49 [in Russian].

5. Zhluktenko, Y.A., Karaban, V.I., Byhovets, N.N. and others (1981). Varianty polinatsionalnyh literaturnyh yazykov. Kiev: Naukova dumka [in Russian].

6. Gak, V.G. (1982). Yazykovaya variantnost v svete obschey teorii variantnosti ( $\mathrm{k}$ probleme faktorov i roli variantnosti v yazyke) [Language variability in the light of the general theory of variance (to the problem of factors and the role of variance in language)]. In Variantnost kak svoystvo yazykovoy sistemy. Tezisy dokladov [Variability as a property of the language system. Abstracts]. Moscow: Nauka (pp. 72-75) [in Russian].

7. Gorbachevich, K.S. (1978). Variantnost slova i yazykovaya norma [Variability of the word and language norm] Leningrad: Nauka [in Russian].

8. Yermolenko, S.Y. (2004). Norma movna [The language norm]. In Ukrainska mova. Entsyklopediia [Ukrainian language. Encyclopedia]. Kyv: Ukrainska entsyklopedia (pp. 420-421) [in Ukrainian]

9. Yermolenko, S.Y. (n.d.). Suchasna literaturna mova i dialekty [Modern literary language and dialects]. URL: http://kulturamovy.univ.kiev.ua/KM/pdfs/Magazine6-2.pdf [in Ukrainian].

10. Zhmaieva, N.S. (2012). Movna norma y variatyvnist [Language norm and variability]. Naukovy visnyk Pivdennoukrainskoho derzhavnoho pedahohichnoho universytetu im. K.D. Ushynskoho. Linhvistychni nauky [Scientific Bulletin of the South Ukrainian State Pedagogical University named after K. D. Ushynsky. Linguistic sciences], 15, 74-82 [in Ukrainian].

11. Itskovich, V.A. (1968). Yazykovaya norma [Language norm]. Moscow: Prosveschenie [in Russian].

12. Koseriu, E. (1963). Sinhroniya, diahroniya i istoriya [Synchrony, diachrony and history]. Novoe v lingvistike [New in linguistics], 3, 143-343 [in Russian].

13. Kots, T. (2016). Yavyshche variantnosti v istorii literaturnoi movy [The phenomenon of variability in the history of literary language]. Ukrainska mova [Ukrainian language], 2, 82-91 [in Ukrainian].

14. Kubryakova, E.S. (1988). O prirode varirovaniya yazykovyh edinits i ego osnovnyh tipah [About the nature of variation of language units and its main types]. In Vsesoyuznaya konferentsiya «Problemy variativnosti v germanskih yazykah». Tezisy dokladov [All-Union Conference «Problems of Variation in Germanic Languages». Abstracts of reports]. Moscow: Nauka (pp. 25-27) [in Russian].

15. Matezius, V. (1989). O lingvisticheskoy harakterologii (na materiale sovremennogo angliyskogo yazyka) [About linguistic characterology (based on the material of modern English)]. In Novoe v zarubezhnoy lingvistike. Kontrastivnaya lingvistika $[\mathrm{New}$ in foreign linguistics. Contrastive linguistics]. Moscow: Progress, Issue XXV (pp. 18-26) [in Russian].

16. Moshnina, T.V. (2000). Dinamika sovremennoy proiznositelnoy normy angliyskogo yazyka [Dynamics of the modern pronunciation norm of English language]. Zvuchaschaya rech: teoriya i praktika [Sounding speech: theory and practice], 453, 131-145 [in Russian].

17. Serebryannikov, B.A. (Ed). Obschee yazykoznanie: Formy suschestvovaniya, funktsii, istoriya yazyka [General linguistics: forms of existence, functions, history of language]. Moscow: Nauka, 1990 [in Russian].

18. Parfinenko, A. (2013). Movna variatyvnist u fokusi suchasnykh linhvistychnykh doslidzhen (na materiali prats brytanskykh ta amerykanskykh vchenykh) [Linguistic variability in the focus of modern linguistic research (based on the works of British and American scientists)]. Studia linguistica, 7, 116-120. URL: http://nbuv.gov.ua/jpdf/Stling_2013_7_21.pdf [in Ukrainian].

19. Solntsev, V.M. (1984). Variativnost kak obschee svoystvo yazykovoy sistemy [Variability as a general property of the language system]. Voprosy yazykoznaniya [Issues of linguistics], 2, 31-42 [in Russian].

20. Fedotova, Y.B. (2011). Aktualnye problemy yazykovoy variativnosti [Actual problems of linguistic variability]. Kultura narodov Prichernomorya [Culture of the peoples of the Black Sea region], 203, 91-94 [in Russian].

21. Shahbagova, D.A. (1982). Foneticheskaya sistema angliyskogo yazyka $\mathrm{v}$ diahronii $\mathrm{i}$ sinhronii (na materiale britanskogo, amerikanskogo, avstraliyskogo, kanadskogo variantov angliyskogo yazyka) [Phonetic system of the English language in diachrony and synchrony (based on the British, American, Australian, Canadian variants of English language)]. Moscow: Vysshaya shkola [in Russian].

22. Yartseva, V.N. (1969). Razvitie natsionalnogo literaturnogo angliyskogo yazyka [Development of the national literary English language]. Moscow: Nauka [in Russian].

23. Yastrezhembskiy, V.R. (1990). Yazykovaya variativnost lingvisticheskoe obyasnenie [Language variability and linguistic explanation]. In Problemy yazykovoy variativnosti: sbornik obzorov [Problems of linguistic variability: collection of articles: reviews]. Moscow: INION (pp. 35-57) [in Russian]. 